I N S T I T U T O

$\mathrm{DE}$

M E D I C I N A

T R O P I C A L

DE

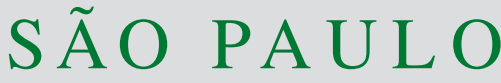

JOURNAL OF THE SÃO PAULO INSTITUTE OF TROPICAL MEDICINE

${ }^{1}$ Universidade Estadual de Montes Claros, Programa de Pós-Graduação em Ciências da Saúde, Montes Claros, Minas Gerais, Brazil

2Universidade Federal de Minas Gerais, Departamento de Medicina Interna, Belo Horizonte, Minas Gerais, Brazil

${ }^{3}$ Universidade de São Paulo, Faculdade de Medicina, Hospital das Clínicas, Laboratório de Medicina Laboratorial (LIM 03), São Paulo, São Paulo, Brazil

${ }^{4}$ Universidade de São Paulo, Instituto de Medicina Tropical de São Paulo, São Paulo, São Paulo, Brazil

${ }^{5}$ Secretaria Municipal de Saúde, Promoção Humana de Espinosa, Espinosa, Minas Gerais, Brazil

'Universidade Federal de São João del-Rei, São João del-Rei, Minas Gerais, Brazil

${ }^{7}$ Hospital Sírio-Libanês, Instituto de Ensino e Pesquisa, São Paulo, São Paulo, Brazil

Correspondence to: Dardiane Santos Cruz Universidade Estadual de Montes Claros, Programa de Pós-Graduação em Ciências da Saúde, Avenida Rui Braga, S/№, CEP 39401-089, Montes Claros, MG, Brazil Tel: +55 38991991064

E-mail: dardisantosc16@gmail.com

Received: 6 April 2021

Accepted: 3 August 2021

\section{Serological screening for Chagas disease in an endemic region of Northern Minas Gerais, Brazil: the SaMi-Trop project}

\author{
Dardiane Santos Cruz ${ }^{\circledR}$, Núbia Nunes de Souza ${ }^{\circledR 1}$, Aline Ferreira Rafael ${ }^{\circledR}$, \\ Renata Fiuza Damasceno ${ }^{1}$, Antonio Luiz Pinho Ribeiro ${ }^{(12}$, Léa Campos \\ de Oliveira ${ }^{\circledR}$, Ester Cerdeira Sabino ${ }^{\circledR}$, Fábio de Rose Ghilardi ${ }^{\circledR}$, Ozorino \\ Caldeira Cruz Neto ${ }^{(5}$, Ariela Mota Ferreira ${ }^{(1)}$, Desirée Sant’Ana Haikal ${ }^{\left({ }^{1}\right.}$, \\ Clareci Silva Cardoso ${ }^{\circledR 6}$, Claudia Di Lorenzo Oliveira ${ }^{\circledR 6}$, Ana Luiza \\ Bierrenbach ${ }^{\circledR 7}$, Thallyta Maria Vieira ${ }^{(1)}$
}

\section{ABSTRACT}

Chagas disease (CD) is still a neglected disease. Infected individuals are diagnosed late, being treated in worse clinical conditions. Thus, this study aimed to analyze the prevalence and the factors associated with new confirmed cases of CD identified by serological screening in an endemic region of Minas Gerais State, Brazil. This is an analytical crosssectional study with data from a project of the Research Center in Tropical Medicine of Sao Paulo- Minas Gerais (SaMi-Trop) conducted in two municipalities. Data collection included a questionnaire with closed questions, a venous blood collection and an ELISA serological test for CD. A total of 2,038 individuals with no previous diagnosis of CD participated in the study. The result of the serological test for CD was adopted as the dependent variable. The independent variables addressed personal issues, health conditions and lifetime housing. A descriptive analysis of individual variables was performed. Subsequently, a bivariate analysis was performed using the Pearson's chi-square test. Households sheltering individuals positive for $\mathrm{CD}$ were georeferenced, and the analysis of spatial distribution was performed using the quartic function to estimate the density of the nucleus. Among the participants, $188(9.2 \%)$ were positive for CD. The profile of participants with CD was associated with place of residence, age, relative/family member with $\mathrm{CD}$ and living conditions. It is noteworthy that there are still patients with $\mathrm{CD}$ who are unaware of their diagnosis in both, rural and urban areas.

KEYWORDS: Chagas disease. Serologic tests. Spatial analysis.

\section{INTRODUCTION}

Chagas disease (CD), caused by the protozoan Trypanosoma cruzi, is a neglected disease $^{1}$. It still constitutes a major social and public health problem in endemic countries, and represents an emerging health problem in non-endemic countries ${ }^{2,3}$. In both places of occurrence, there is inexperience of health professionals $s^{4,5}$ and a high rate of underdiagnosis ${ }^{2,5-7}$.

It is estimated that 6 to 7 million people are infected worldwide ${ }^{8}$. In Brazil, it was estimated that between 1.3 and 3.2 million people would be infected with T. cruzi in $2020^{2}$. However, the country does not have data on the prevalence of chronic $\mathrm{CD}$. Although the notification of chronic cases of $\mathrm{CD}$ became mandatory in $2020^{9}$, the $\mathrm{CD}$ control program is disjointed and its actions are discontinuous ${ }^{10}$. 
From 2009 to $2018,45,863$ deaths were recorded in Brazil as a result of $\mathrm{CD}^{11}$. Of these, $11,343(24.7 \%)$ were registered in the Brazilian Minas Gerais State, and the highest number of deaths, 2,300 or $20.2 \%$, were reported by the Northern health macro-region ${ }^{11}$. Although much of Northern Minas Gerais has been identified as an area of high risk for vector transmission of $\mathrm{CD}$ or of reestablished home transmission ${ }^{12}$, there is no investigation of $\mathrm{CD}$ in the prenatal care routine ${ }^{13}$ and many infected people are unaware of their condition ${ }^{14}$.

The late diagnosis of $\mathrm{CD}$ makes infected people arrive in worse clinical conditions to the health system, favoring the evolution of the disease, decreasing the quality of life of infected individuals, increasing their morbidity and mortality and causing a significant economic loss ${ }^{15-17}$. The absence of accessible diagnostic methods and the lack of specific information on $\mathrm{CD}$ by health professionals, leaves infected individuals unidentified, and therefore, untreated ${ }^{4,18}$. This reality mainly affects vulnerable populations ${ }^{13}$. An early diagnosis allows the access to an appropriate treatment, minimizing complications of the disease, and lowering the corresponding mortality ${ }^{2}$. In addition, it is recommended that the diagnosis be made in all suspected cases ${ }^{2}$.

Thus, this study aimed to analyze the prevalence and the factors associated with new confirmed cases of CD identified by serological screening in an endemic region of Minas Gerais State, Brazil.

\section{MATERIALS AND METHODS}

\section{Ethical approval}

This study was approved by the Ethics Committee of the State University of Montes Claros (CEP/UNIMONTES $\left.\mathrm{N}^{\circ} 3.502 .440 / 2018\right)$. All participants agreed to participate in this study and signed the Informed Consent Form.

\section{Study design}

This is a cross-sectional analytical study with data from a project performed at the Center for Research in Tropical Medicine of Sao Paulo-Minas Gerais (Centro de Pesquisa em Medicina Tropical de Sao Paulo-Minas Gerais - SaMi-Trop). This multicenter project is carried out by researchers from four Brazilian public universities in the States of Minas Gerais and Sao Paulo, Brazil. Its purpose is to develop and conduct research projects on CD.

\section{Study area}

This study was conducted in two municipalities in the Northern region of the Brazilian State of Minas Gerais: Espinosa (Latitude: $15^{\circ} 56^{\prime} 55^{\prime \prime}$ South; Longitude 44.51'52" West) and Sao Francisco

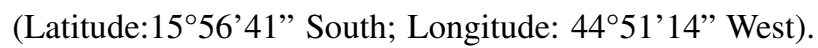
The territorial extension of Espinosa is $1,884.23 \mathrm{~km}^{2}$ and of Sao Francisco is $3,312.27 \mathrm{~km}^{2}$. The population of Espinosa comprises 31,113 inhabitants and of Sao Francisco 53,828 ${ }^{19}$. Both municipalities have high coverages of the Family Health Strategy (FHS) and more than 98\% of the population depends on the Primary Health Care (PHC) offered by the Public Health System (Sistema Unico de Saude - SUS) ${ }^{20}$.

\section{Sample}

Individuals over the age of 18 and belonging to the FHS coverage area were invited. The sample was defined in a non-probabilistic way. The exclusion criterion was: individuals with a previous diagnosis of $\mathrm{CD}$.

A total of 2,056 individuals participated in the stage of sample collection. However, for this study, 18 individuals who reported having been diagnosed with $\mathrm{CD}$ were excluded from the analysis, thus 2,038 were eligible.

\section{Data collection}

A meeting was held with the managers and nurses responsible for the FHS of the respective municipalities in order to inform them on the planned intervention and request their consent to carry out the study. After their acceptance, the municipalities made available an accessible FHS unit to carry out the data collection. Nurses passed on the information to the community health workers (CHW). Then, upon a scheduled date, the CHW invited the community to participate in the study and informed that more than one family member could participate.

The data collection took place between February and November 2019, and included a questionnaire with closed questions and one collection of venous blood. The questionnaire was applied to the participants with the questions addressing personal information, health and housing conditions during their lives.

\section{Serological screening}

The collected venous blood samples were centrifuged the resulting serum was stored at $-20^{\circ} \mathrm{C}$ and subsequently sent in dry ice to the Institute of Tropical Medicine of the University of Sao Paulo (IMT-USP), where two enzyme linked immune sorbent assays (ELISA) tests were performed in duplicate, using commercial kits (Chagatest, Wiener Lab, Rosario, Argentina, and Trypanosoma cruzi 
IgG, Euroimmun, Lübeck, Germany) according to the manufacturer's instructions. To confirm the serological diagnosis, it was necessary to obtain concordant results in at least two serological tests of different methodological principles or antigenic preparations ${ }^{2}$.

Individuals identified with $\mathrm{CD}$ who authorized the notification of their condition, and those with inconclusive serology, were included in the flow of the Brazilian unified health system for the continuity of their health care and treatment of CD.

\section{Variables}

The results of the ELISA tests were adopted as the outcome (dependent variable), dichotomized into two categories (negative/inconclusive vs. positive). The independent variables were composed by city, age, gender, relative/family member with $\mathrm{CD}$, knowledge on triatomine insects, have lived in an area with triatomine insects, have lived in a wooden/wattle and daub/adobe house. The age was calculated based on the date of birth of the participants and categorized as: up to 35 years, from 36 to 55 years, from 56 to 75 and 76 years or more.

\section{Statistical analysis}

The descriptive analysis of individual variables was performed, estimating absolute (n) and relative (\%) frequencies for the categorical variables and calculating the central tendency and dispersion measures for the numerical variables. Subsequently, a bivariate analysis was performed using the Pearson's chi-square test, considering only the associations that maintained a significance level of up to $5 \%(\mathrm{p}<0.05)$. The statistical software Statistical Package for the Social Sciences (SPSS) V.19 (SPSS Inc., IBM, Armonk, New York, USA) was used to carry out the analyzes conducted in this study.

The households that sheltered individuals serological positive for $\mathrm{CD}$ were georeferenced on site using a Global Positioning System (GPS) navigation device (Garmin Etrex $^{\circledR}$ Garmin Ltd., Olathe, USA). In the Qgis 3.4 ${ }^{\circledR}$ program (version 3.4 Madeira, QGIS Development Team), the spatial distribution analysis of the residences was carried out using the quartic function of the kernel density estimation $(\mathrm{KDE})^{21}$, considering a bandwidth of $500 \mathrm{~m}$. KDE is a non-parametric function that estimates probable occurrence values based on the density of upcoming events.

\section{RESULTS}

A total of 2,038 individuals participated in this study, of which $188(9.2 \%)$ were serologically positive, 48 (2.6\%) were inconclusive and 1,850 (90.8\%) were negative for $\mathrm{CD}$. The inconclusive tests were repeated when these individuals were entered into the SUS, but for logistical and ethical reasons, we did not have access to these results. Among the participants, the majority live in the city of Sao Francisco, are female (63.5\%), have a mean age of 48.18 years $( \pm 15.43)$, with a minimum age of 18 and a maximum of 94 years. They reported to be related to people with CD $(50.8 \%)$, not having been bitten by triatomine insects $(60.3 \%)$, having lived in an area with triatomine insects $(87.1 \%)$, and having lived in a wooden/wattle and daub/adobe house $(72.2 \%)$ (Table 1).

Among the individuals diagnosed with $\mathrm{CD}$, the mean age was $56.19( \pm 9.02)$ years with a minimum of 35 and a maximum of 86 years old. The majority of individuals with a diagnosis of CD lived in the city of Espinosa (12\%), while the majority of respondents lived in the city of Sao Francisco. When analyzing the distribution of positive diagnoses in the cities studied (Figure 1, Table 2), it was observed that $75 \%$ of positive cases live in the rural area of Espinosa and $55 \%$ live in the urban area of Sao Francisco.

In the bivariate analysis, it was observed that the characteristics that were statistically associated with positive diagnoses were age, having a family member with $\mathrm{CD}$, have been bitten by the triatomine insect, have lived in an area with triatomine insects, and have lived in a wooden/ wattle and daub/adobe house (Table 1).

The individual variables that were statistically associated with the outcome were age, being related to people with $\mathrm{CD}$, having been bitten by the triatomine insect, having lived in an area with triatomine insects, and have lived in a wooden house/wattle and daub/adobe.

\section{DISCUSSION}

The present study observed that the number of positive cases screened by serology corroborates the number of positive cases estimated by the high-risk population of the Clinical Protocol and Therapeutic Guideline for Chagas Disease (PCDT) 22 .

With the increase in migration and progressive changes in the rural economy, the epidemiological patterns of $\mathrm{CD}$ have been modified, with a transition from acute rural to chronic urban disease ${ }^{23}$. In Minas Gerais State, it was observed that between 2001 and 2006, 84 cases of acute $\mathrm{CD}$ were reported, with $58 \%$ of the cases of acute $\mathrm{CD}$ being registered in the urban $\operatorname{area}^{24}$, a significant data, since for decades $\mathrm{CD}$ was restricted to rural areas and was strongly marked by poverty ${ }^{2}$. However, our study shows that it is not possible to generalize the epidemiological patterns of $\mathrm{CD}$, 
Table 1 - Descriptive and bivariate analysis of the diagnoses of Chagas disease $(n=2,038)$.

\begin{tabular}{|c|c|c|c|c|}
\hline \multirow{3}{*}{ Characteristics } & \multirow{3}{*}{$\begin{array}{c}\text { Descriptive } \\
\mathrm{n}(\%)\end{array}$} & \multicolumn{2}{|c|}{ Bivariate } & \multirow{3}{*}{$P$-value } \\
\hline & & \multicolumn{2}{|c|}{ New positives } & \\
\hline & & $\begin{array}{c}\text { Negative/inconclusive } \\
\mathrm{n}(\%)\end{array}$ & $\begin{array}{c}\text { Positive } \\
\text { n (\%) }\end{array}$ & \\
\hline \multicolumn{5}{|l|}{ Individuals } \\
\hline \multicolumn{5}{|l|}{ City } \\
\hline Espinosa & 897 (44\%) & $789(88 \%)$ & $108(12 \%)$ & $<0.001$ \\
\hline Sao Francisco & $1,141(56 \%)$ & $1,061(93 \%)$ & $80(7 \%)$ & \\
\hline \multicolumn{5}{|l|}{ Age in years* } \\
\hline Up to 35 & $454(22.1 \%)$ & $453(99.8 \%)$ & $1(0.2 \%)$ & $<0.001$ \\
\hline 36 to 55 & $884(43.4 \%)$ & $795(89.9 \%)$ & $89(10.1 \%)$ & \\
\hline 56 to 75 & $614(30.1 \%)$ & $523(85.2 \%)$ & $91(14.8 \%)$ & \\
\hline 76 of or more & $84(4.1 \%)$ & $77(91.7 \%)$ & $7(8.3 \%)$ & \\
\hline \multicolumn{5}{|l|}{ Gender } \\
\hline Male & $743(36.5 \%)$ & $664(89.4 \%)$ & $79(10.6 \%)$ & 0.096 \\
\hline Female & $1,295(63.5 \%)$ & $1,186(91.6 \%)$ & 109 (8.4\%) & \\
\hline \multicolumn{5}{|c|}{ Relative/family member with $C^{*}$} \\
\hline No & $846(49.2 \%)$ & $793(93.7 \%)$ & $53(6.3 \%)$ & $<0.001$ \\
\hline Yes & $875(50.8 \%)$ & $775(88.6 \%)$ & $100(11.4 \%)$ & \\
\hline \multicolumn{5}{|l|}{ Triatomine insect $^{\star}$} \\
\hline No & $786(60.3 \%)$ & $742(94.4 \%)$ & $44(5.6 \%)$ & $<0.001$ \\
\hline Yes & $518(39.7 \%)$ & $444(85.7 \%)$ & $74(14.3 \%)$ & \\
\hline \multicolumn{5}{|c|}{ Lived in an area with triatomine insects ${ }^{*}$} \\
\hline No & $256(12.9 \%)$ & $248(96.9 \%)$ & $8(3.1 \%)$ & 0.001 \\
\hline Yes & $1,732(87.1 \%)$ & $1,556(89.8 \%)$ & $176(10.2 \%)$ & \\
\hline \multicolumn{5}{|c|}{$\begin{array}{l}\text { Lived in a wooden/wattle and } \\
\text { daub/adobe house }\end{array}$} \\
\hline No & $565(27.8 \%)$ & $549(97.2 \%)$ & $16(2.8 \%)$ & $<0.001$ \\
\hline Yes & $1,469(72.2 \%)$ & $1,298(88.4 \%)$ & $171(11.6 \%)$ & \\
\hline
\end{tabular}

${ }^{*}$ Variation of $n=2,038$ due to missing information.

as the municipality of Sao Francisco presented an urban pattern, but the municipality of Espinosa presented a rural pattern. CD is still recognized as a neglected disease, which mainly affects vulnerable populations in need of public policies that promote access to health care ${ }^{1}$.

Regarding the age, our study corroborates the results of others ${ }^{25,26}$ who observed a greater relationship between positive serology and older people, suggesting that the infection by T. cruzi has happened in the past. From the 1950s to the mid-1990s, campaigns to prevent CD were intensified, and since then, vector transmission has suffered a significant decrease. As a consequence, it is possible that the positive individuals in the study became infected in a period prior to the campaigns to combat $\mathrm{CD}^{2,26,27}$. Another factor to consider would be the lack of adequate training of PHC professionals during their under graduation studies as well as their professional lives, leading to the failure to consider the suspicion of $\mathrm{CD}$ in their patients ${ }^{4}$, making the early diagnosis and treatment unfeasible.

Having a relative/family member with $C D$ was associated with a positive diagnosis. Other studies have also observed a history of $\mathrm{CD}$ in the families of diagnosed patients ${ }^{28,29}$. The authors hypothesized that these infections occurred through vector transmission, due to their region of birth, being in the rural area or in an endemic area, and the presence of triatomine insects in the households ${ }^{28,29}$. This demonstrates the relevance of medical care to the entire family group. In addition, another possibility of infection is through congenital transmission ${ }^{12}$. A systematic review with meta-analysis carried out in Brazil, in 2014, reported a congenital transmission rate ranging from 0 to $5.2 \%{ }^{30}$. The WHO recommends that all pregnant women be subjected to serology to $T$. cruzi $^{31}$, but this has not yet been achieved, and $\mathrm{CD}$ continues to be neglected and excluded from the prenatal care examinations ${ }^{13}$.

Having previous contact with the $C D$ vector through a triatomine bite was associated with a positive diagnosis. In 2006, Brazil was certified for the interruption of the transmission of $\mathrm{CD}$ by its main vector, and also made progress in the transfusion screening ${ }^{32}$. Even in the face of these achievements, an alert is essential, as it is still possible to find residual foci in the Brazilian territory 


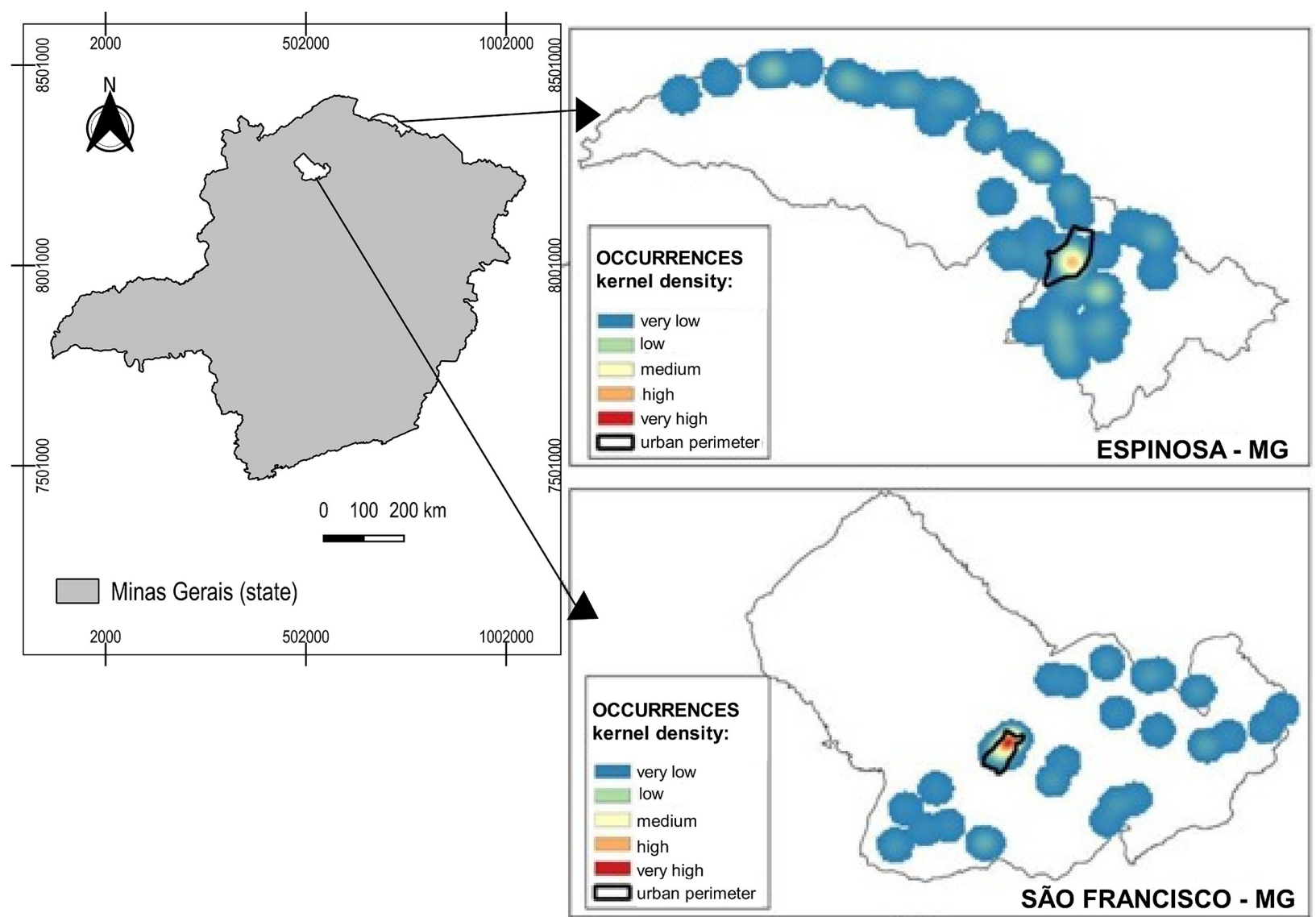

Figure 1 - Spatial distribution of cases diagnosed with Chagas disease in 2019, in the municipalities of Espinosa and Sao Francisco, Minas Gerais State $(n=2,038)$.

Table 2 - Description of the place of residence of the individuals participating in the study $(n=2,038)$.

\begin{tabular}{lcccccccc}
\hline \multirow{2}{*}{ Municipality } & \multicolumn{3}{c}{ Individuals surveyed } & & \multicolumn{3}{c}{ Individuals diagnosed with CD } \\
\cline { 2 - 4 } & Rural zone & Urban zone & Total & & Rural zone & Urban zone & Total \\
\hline Espinosa & $377(42.03 \%)$ & $520(57.97 \%)$ & $897(44 \%)$ & & $81(75 \%)$ & $27(25 \%)$ & $108(12 \%)$ \\
Sao Francisco & $417(36.55 \%)$ & $724(63.45 \%)$ & $1141(56 \%)$ & & $36(45 \%)$ & $44(55 \%)$ & $80(7 \%)$ \\
\hline
\end{tabular}

capable of reintroducing the main vector of $\mathrm{CD}^{32}$. Bearing in mind that the studied municipalities are currently located in areas at risk of transmission of CD due to the presence of the vector, we cannot rule out the possibility of vector transmission in the individuals participating in the study, therefore continuous epidemiological surveillance actions are necessary ${ }^{12}$. The CD control program is in the epidemiological surveillance phase, where the population has a fundamental role, but many people do not have knowledge on the management and identification of the vector, making this type of control vulnerable ${ }^{33,34}$. A study carried out in Diamantina (Minas Gerais State) demonstrated that the population's knowledge on the identification of the $\mathrm{CD}$ vector is indispensable for the correct referral of insects to the control service. In areas where people had sufficient knowledge to identify the vector, entomological surveillance actions were more assiduous ${ }^{35}$. This indicates the need to carry out health education activities, because, through alerting and bringing knowledge, it is possible to achieve an effective control.

Living in a wooden, wattle and daub, or adobe house at some point in life was related to positive serology. Housing characteristics have already been reported to be significantly associated with domestic infestation of the $\mathrm{CD}$ vector $^{36}$. Houses built with wood, wattle and daub, or adobe have refuges that are ideal shelters for vector infestation, thus making their residents a food source, increasing the chances of infection by $T$. cruzi ${ }^{36}$. Despite the Federal Government's incentive aimed to improve the civil construction in endemic regions of Brazil ${ }^{37}$, it is still possible to find precarious households in rural communities in the country. Adequate housing infrastructure generates 
positive impacts on health in general, thus the improvement of households is an important factor for vector control, as a long-term strategy ${ }^{37}$.

In the development of this study, some limitations were observed, among them the cross-sectional design, which does not allow establishing causal relationships. IN addition, there is a limitation of temporality, as it is not possible to verify when these people were infected. However, this type of design allows to characterize the population and identify risk groups. One of the strengths of our study was the high detection rate of patients with CD who were unaware of their condition. The low visibility of these individuals in the society is notorious and our study shows the deficit in coping with CD along with the PHC, which is the closest health resource for the population. Although a PCDT for CD was instituted in 2018 by the Ministry of Health, there is still no specific line of care for chronic CD patients ${ }^{22}$. CD continues to be neglected even one hundred years after its discovery, demonstrating the importance of actively searching for new CD carriers in an endemic region.

\section{CONCLUSION}

The profile of participants with positive CD serology identified in this study is associated with place of residence, age, family and life conditions. Our study demonstrates that in both, rural and urban areas, there are still people with CD who are unaware of their diagnosis. $\mathrm{CD}$ remains a major challenge for the SUS, thus it is necessary that the PHC together with the epidemiological surveillance establish effective protocols for the screening and management of CD.

\section{ACKNOWLEDGMENTS}

We thank the SaMi-Trop project team, the patients in this study and the National Institutes of Health (NIH).

\section{FUNDING}

National Institutes of Health (NIH) (P50 AI098461-02).

\section{REFERENCES}

1. Pinheiro E, Brum-Soares L, Reis R, Cubides JC. Chagas disease: review of needs, neglect, and obstacles to treatment access in Latin America. Rev Soc Bras Med Trop 2017;50:296-300.

2. Dias JC, Ramos Jr. AN, Gontijo ED, Luquetti A, Shikanai-Yasuda MA, Coura JR, et al. II Consenso Brasileiro em Doença de Chagas, 2015. Epidemiol Serv Saude. 2016;25:7-86.
3. Nunes MC, Dones W, Morillo CA, Encina JJ, Ribeiro AL. Chagas disease: an overview of clinical and epidemiological aspects. J Am Coll Cardiol. 2013;62:767-76.

4. Ferreira AM, Sabino EC, Moreira HF, Cardoso CS, Oliveira CD, Ribeiro AL, et al. Avaliação do conhecimento acerca do manejo clínico de portadores da doença de Chagas em região endêmica no Brasil. Rev APS. 2018;21:345-54.

5. Stimpert KK, Montgomery SP. Physician awareness of Chagas disease, USA. Emerg Infect Dis. 2010;16:871-2.

6. Basile L, Jansa JM, Carlier Y, Salamanca DD, Angheben A, Bartoloni A, et al. Chagas disease in european countries: the challenge of a surveillance system. Euro Surveill. 2011;16:19968.

7. Cortez J, Ramos E, Valente C, Seixas J, Vieira A. A expressão global da doença de Chagas: oportunidades emergentes e impacto em Portugal. Acta Med Port. 2012;25:332-9.

8. World Health Organization. Chagas disease (also known as American trypanosomiasis). [cited 2021 Aug 3]. Available from: https://www.who.int/news-room/fact-sheets/detail/ chagas-disease-(american-trypanosomiasis)

9. Brasil. Ministério da Saúde. Gabinete do Ministro. Portaria n ${ }^{\circ} 264$, de 17 de fevereiro de 2020. Altera a Portaria de Consolidação $\mathrm{n}^{\circ}$ 4/GM/MS, de 28 de setembro de 2017, para incluir a doença de Chagas crônica, na Lista Nacional de Notificação Compulsória de doenças, agravos e eventos de saúde pública nos serviços de saúde públicos e privados em todo o território nacional. Diário Oficial da União, Brasília, 19 fev. 2020. Seção 1:97. [cited 2021 Aug 3]. Available from: https://www. in.gov.br/en/web/dou/-/portaria-n-264-de-17-de-fevereirode-2020-244043656

10. Silveira AC. El impacto de la descentralización de los sistemas de salud em la prevención y control de la enfermedad de Chagas: el caso del Brasil. In: Yadón ZE, Gurtler RE, Tobar F, Medici AC, editores. Descentralización y manejo del control de enfermidades transmisibles en América Latina. Buenos Aires: OPS; 2006. p.203-14.

11. Brasil. Ministério da Saúde. DATASUS: informações de saúde (TABNET): estatísticas vitais. [cited 2021 Aug 3]. Available from: http://www2.datasus.gov.br/DATASUS/index.php?ar ea $=0205 \& i d=6937 \& \mathrm{VObj}=\mathrm{http}: / /$ tabnet.datasus.gov.br/cgi/ deftohtm.exe?sim/cnv/obt1

12. Galvão C, organizador. Vetores da doença de Chagas no Brasil. Curitiba: Sociedade Brasileira de Zoologia; 2014.

13. São Paulo. Secretaria da Saúde. Coordenadoria de Planejamento em Saúde. Assessoria Técnica em Saúde da Mulher. Atenção a gestante e a puérpera no SUS-SP: manual técnico do prénatal e puerpério. São Paulo: Secretaria da Sáude; 2010. [cited 2021 Aug 3]. Available from: http://www.saude.sp.gov.br/ resources/ses/perfil/gestor/destaques/atencao-a-gestante-e-apuerpera-no-sus-sp/manual-tecnico-do-pre-natal-e-puerperio/ manual_tecnicoii.pdf 
14. Pecoul B, Batista C, Stobbaerts E, Ribeiro I, Vilasanjuan R, Gascon J, et al. The BENEFIT trial: where do we go from here ? PLoS Negl Trop Dis. 2016; 10:e0004343.

15. Brasil. Ministério da Saúde. Secretaria de Vigilância em Saúde. Doença de Chagas aguda no Brasil: série histórica de 2000 a 2013. Bol Epidemiol. 2015;46:1-9. [cited 2021 Aug 3]. Available from: https://antigo.saude.gov.br/images/pdf/2015/ agosto/03/2014-020.pdf

16. Araújo SM, Andó MH, Cassarotti DJ, Mota DC, Borges SM, Gomes ML. Programa ACHEI: Atenção ao Chagásico com Educação Integral no município de Maringá e Região Noroeste do Paraná, Brasil. Rev Soc Bras Med Trop. 2000;33:565-72.

17 Franco-Paredes C, Von A, Hidron A, Rodríguez-Morales AJ, Tellez I, Barragán M, et al. Chagas disease : an impediment in achieving the Millennium Development Goals in Latin America. BMC Int Health Hum Rights. 2007;7:7.

18. Balouz V, Aguero F, Buscaglia CA. Chagas disease diagnostic applications: present knowledge and future steps. Adv Parasitol. 2017;97:1-45.

19. Programa das Nações Unidas para o Desenvolvimento. Fundação João Pinheiro. Instituto de Pesquisa Econômica Aplicada. Atlas de desenvolvimento humano no Brasil. [cited 2021 Aug 3]. Available from: https://atlasbrasil.org.br/

20. Brasil. Ministério da Saúde. Secretaria de Atenção Primária à Saúde. Departamento de Saúde da Família. Sistema de nota técnica do DESF. [cited 2021 Aug 3]. Available from: https:// sisaps.saude.gov.br/notatecnica/frmListaMunic.php

21. Gatrell AC, Bailey TC, Diggle PJ, Rowlingson BS. Spatial point pattern analysis and its application in geographical epidemiology. Trans Inst Br Geogr. 1996;21:256-74.

22. Brasil. Ministério da Saúde. Comissão Nacional de Incorporação de Tecnologias no SUS. Protocolo clínico e diretrizes terapêuticas: doença de Chagas. Brasília: Ministério da Saúde; 2018. [cited 2021 Aug 3]. Available from: http://conitec. gov.br/images/Consultas/Relatorios/2018/Relatorio_PCDT_ DoencaChagas_CP42_2018.pdf

23. World Health Organization. Chagas disease (American trypanosomiasis). [cited 2021 Aug 3]. Available from: https:// www.who.int/news-room/q-a-detail/chagas-disease

24. Pereira CM, Azevedo AP, Marinho SS, Prince KA, Gonçalves JT, Costa MR, et al. Perfil clínico e epidemiológico da doença de Chagas aguda no estado de Minas Gerais. Rev Aten Saude. 2017;15:49-54

25. Vizzoni AG, Varela MC, Sangenis LH, Hasslocher-Moreno AM, Brasil PE, Saraiva RM. Ageing with Chagas disease: an overview of an urban Brazilian cohort in Rio de Janeiro. Parasit Vectors. 2018;11:354.

26. Matos CS, Santos Júnior JE, Medeiros FA, Furtado E, Dias JC. Current situation and perspectives regarding human Chagas disease in midwestern of the state of Minas Gerais, Brazil. Mem Inst Oswaldo Cruz. 2014;109:374-8.
27. Glass IR, Santos AD, Varjão AE, Costa IS, Correia D, Silva AM. Clinical and epidemiological characteristics of Chagas disease in an endemic area of Sergipe State, Brazil. Rev Soc Bras Med Trop. 2018;51:660-4.

28. Gontijo ED, Rocha MO, Oliveira UT. Perfil clínico-epidemiológico de chagásicos atendidos em ambulatório de referência e proposição de modelo de atenção ao chagásico na perspectiva do SUS. Rev Soc Bras Med Trop. 1996;29:101-8.

29. Bozelli CE, Araújo SM, Guilherme AL, Gomes ML. Perfil clínico-epidemiológico de pacientes com doença de Chagas no Hospital Universitário de Maringá, Paraná, Brasil. Cad Saude Publica. 2006;22:1027-34.

30. Martins-Melo FR, Lima MS, Ramos Jr AN, Alencar CH, Heukelbach J. Prevalence of Chagas disease in pregnant women and congenital transmission of Trypanosoma cruzi in Brazil : a systematic review and meta-analysis. Trop Med Int Health. 2014;19:943-57.

31. Organização Pan-Americana da Saúde. Organização Mundial da Saúde. Enfermedad de Chagas en las Américas: una revisión de la situación actual de salud pública y su visión para el futuro: informe: conclusiones y recomendaciones, Washington D.C., mayo 3 y 4 de 2018. [cited 2021 Aug 3]. Available from: https:// www.paho.org/hq/index.php?option=com_content\&view=art icle\&id=14399: enfermedad-chagas-en-americas-revision-desituacion-vision-futuro \&Itemid=72315\&lang=en

32. Silveira AC. Os novos desafios e perspectivas futuras do controle. Rev Soc Bras Med Trop. 2011;44 Suppl 2:122-4.

33. Santos CV, Bedin C, Wilhelms TS, Villela MM. Assessment of the housing improvement program for Chagas disease control in the Northwestern municipalities of Rio Grande do Sul, Brazil. Rev Soc Bras Med Trop. 2016;49:572-8.

34. De Urioste-Stone SM, Pennington PM, Pellecer E, Aguilar TM, Samayoa G, Perdomo HD, et al. Development of a communitybased intervention for the control of Chagas disease based on peridomestic animal management: an eco-bio-social perspective. Trans R Soc Trop Med Hyg. 2015;109:159-67.

35. Dias JV, Queiroz DR, Diotaiuti L, Pires HH. Knowledge of triatomine insects and of the Chagas disease among people from localities which have different levels of vector infestations. Cien Saude Colet. 2016;21:2293-304

36. Gaspe MS, Provecho YM, Cardinal MV, Fernández MP, Gürtler RE. Ecological and sociodemographic determinants of house infestation by Triatoma infestans in indigenous communities of the Argentine Chaco. PLoS Negl Trop Dis. 2015;9: e0003614.

37. Brasil. Fundação Nacional de Saúde. Elaboração de projeto de melhoria habitacional para o controle da doença de chagas. Brasília: Funasa; 2013. [cited 2021 Aug 3]. Available from: http://www.funasa.gov.br/documents/20182/34758/elab_proj_ melh_hab_cont_doen_chagas_2.pdf/4b57c475-5812-43e09ad3-ed4ebf150070 